\title{
Integrated Character Education Model in Early Childhood Education Based on Minangkabau Local Culture: Randai
}

\author{
Nurlaila Tussubha ${ }^{1}$ and Hadiyanto ${ }^{2}$ \\ ${ }^{l}$ Master of Early Childhood Education, Faculty of Education, Universitas Negeri Padang, email: ella.arifin@ gmail.com \\ ${ }^{2}$ Faculty of Education, Universitas Negeri Padang, email: hadiyanto@fip.unp.ac.id
}

\begin{abstract}
The crisis of character is closely related to the crisis of cultures. The most appropriate character education should be given at an early age, because this golden age will later determine the adulthood. The early age is called as the golden age because this is the time when a child's brain develops rapidly. Randai is a game and also an art, a part of the local wisdom of Minangkabau's culture, laden with religious, philosophical and ethical values. Randai could be a means to the early childhood character education and also preserves our local cultures. The Minangkabau people uphold the "adat basandi syara', syara' basandi kitabullah" priciple. This article aims to identify and describe the integrated character education values of the early childhood education, based on the local culture of Randai. This article is based on the literature review of existing literatures.
\end{abstract}

Keywords: Early Childhood Education, Culture, Randai

\section{INTRODUCTION}

The crisis of character that engulfs the nation is increasingly apprehensive to various circles. Whereas since the era of Sukarno's presidential administration, character building has been proclaimed with the term National character building, which means that the progress of a nation is not due to natural resources only, but more importantly is the development of human resources through character building (Alawiyah, 2012). National character building is an important and inseparable part of national development (Marzuki, 2015).

One of the functions of national education in Law Number 20 Year 2003, concerning the National Education System, article 3 is to establish a dignified character and civilization of the nation, and one of the objectives is that students become noble, healthy, knowledgeable, competent, creative, independent and become a democratic and responsible civilian". Whereas Presidential Regulation Number 87 of 2017 concerning Strengthening Character Education states: "Indonesia as a cultured nation is a country that upholds noble character, noble values of wisdom and character." Learning should no longer be focused on developing cognitive-intlualistic and formalistic aspects. The effective character building is through education.

According to Vigotsky, 'Education plays an important role in helping children learn cultural tools. Cultural contribution, social interaction and history are very influential in the development of children's mental / behavior. "Education serves to empower the human potential to inherit, shape and build the culture and civilization of the future, to preserve positive cultural values for the survival of human life (Warsiti, 2015). The appropriate character education is begun at an early age.

Early childhood is the best time of the process of learning with a variety of stimulation that goes very fast. This is the period when children's brain cells increasing very rapidly. This is right time to provide education and character education for shaping the personal identity (Hidayah, 2015). Thomas Lickona said, "Children are 25 percent of population but 100 percent of the future" (Lickona, 2004).

Through the early childhood education, children are expected to be able to develop the spiritual, moral, emotional, social, and intellectual intelligence of the nation's next generation. Character education of children from an early age can be built through the inculcation of local wisdom values. Character education could make children to have noble morals, and can increase academic success. Nation character building needs to be developed from the early age (Lukitasari, 2017). Character education is not only the responsibility of teachers in the schools, because children's character education could be built through the trinity of education centers, namely families, schools and communities (Hidayah, 2015). Children who have a character that has been formed from the early age are expected to be able to survive and not be swayed by influences that are increasingly worrying (Rahayu, 2018). 
I. Randai is a game as well as local Minangkabau cultural arts. Local wisdom could be values, norms, ethics, beliefs, customs, laws, customs, special rules. The life of the Minangkabau people is strongly adhering to the adaek basandi syara ', syara' basandi Kitabullah. Syara 'mangato, Adaek mamakai. The customary and religious philosophy adopted by the Minangkabau people is gathered in randai (Bahardur, 2018).

\section{THEORETICAL BASIS}

\section{A. The Understanding Early Childhood}

NAEYC (National Association for Education of Young Children), early childhood is a child in the age range of $0-8$ years, which is covered by educational programs in childcares, family childcare home, preschool education (private and public), kindergarten and elementary school (Amini, 2014) which have unique characteristics, and all of these are in the process of very rapid and fundamental development for the next phase of life, a period of exploration, a period of identification / imitation, a sensitive period, a period of play, and early defiance period. Also called a critical period, where the golden age period is not optimally and maximally stimulated (Suryana, 2013). 80\% of the growth elasticity of a child's brain develops greater from birth until the age of 8 years. The remaining 20\% is determined in the period after childhood (Khadijah, 2016). Meanwhile, according to Ki Hajar Dewantara, it is called a sensitive period, an important period for a child's life, a time for a child's soul to be opened so that all experiences received by children under seven years will be the basis of a permanent soul (Magta, 2013).

Based on those understandings, it can be concluded that the early childhood is the child at the age range of 0-8 years, it's also called as the golden age phase which is the time of the child has the potential intelligence, sensitive period, the right time to form the basis of behavior and provide encouragement and stimulation of education that persists in the soul of a child.

\section{B. Characteristics of Early Childhood}

According to Piaget, early childhood has an active and curious nature that is useful for shaping knowledge and understanding through a process of adaption experience to the environment (Magta, 2013). As an active student, his experience and knowledge physically and socially will be transmitted to build understanding of his environment. The initial experience a child is cumulative, which means that if the experience occurs repeatedly and often, then the effect could be strengthened, increased, even lasting. (Suryana, 2013). As the impersonator, the teacher plays a big role as a role model for children in the school, so that what the child imitates from the teacher in the form of words, behavior, and appearance shows something positive and praiseworthy (Mayar, 2013). Full of laughter and active moves. Children have a great curiosity (curiosity), is a unique person, likes to fantasize and imagine, the most potential time for learning, egocentric, children have a short span of concentration power (Amini, 2014).

Based on these explanations, could be concluded that early childhood has unique characteristics, the teacher must provide stimulation of all aspects of development, be a model, and provide services according to the characteristics of the child so that children can grow and develop optimally and have a laudable character.

\section{Definition of Early Childhood Education}

According to Sibak and Vinter, Early childhood education is the branch of educational ory wich relates to teaching of young children up to the age of about eight wich a particular focus on developmental education most notable before the strata of compulsory education (Ahsanah, 2018). Ki Hajar Dewantara states, early childhood education is education to add to the soul's content in developing the five senses and aspects of early childhood development, which runs naturally and liberally, with the guidance from educators with a culture-based tutoring system (Magta, 2013) . Early education in human formation, the foundation in laying the foundations of education in providing knowledge also introduces a cultural environment for children's growth and development integrated with character education for preparing human beings with good quality. (Suryana, 2016).

Early childhood education programs are programs that guide early childhood teaching and learning based on theories in the applied curriculum (Morrison, 2012). Early childhood education is positive parenting and guidance to develop positive behaviors that God Almighty has given to the children (Prasetyo, 2011). The aim of early childhood education is helping to lay the foundation for the development of attitudes, behaviors, recognition, skills and creativity that are needed by children in their growth and development (Suryana, 2018). Vigotsky, helping children master cultural tools in their environment (Roopnarine, 2011), locally-based learning menus are useful for shaping the character of early childhood (Larasati, 2010). Schools play a very important role in developing children's character (Hadiyanto, 2013)

Based on those descriptions, early childhood education is an educational effort that provides care and services for children to help the growth and development of the physical and spiritual child, in stimulating the basic attitudes, knowledge and skills integrated with character education in accordance with the culture of their environment.

D. The importance of character education in early childhood education

- Understanding Character

Confucious, a chinese philosopher states that basically humans have the potential to love virtue, if this potential is not followed by education and socialization after humans are born, then humans can turn into animals, even worse (Kaimuddin, 2014). The character comes from the original culture of Indonesian people. Character education in Indonesia is supported by 
cultural values contained therein. (Suryana, 2016). According to Thomas Lickona, the characters are: a realiable inner disposition to respond to situations in a morally good way. Character is formed from three components, namely moral knowing, moral feeling, and moral behavior. Good character includes the knowledge of goodness, then gives rise to a commitment or (intention) towards and actually doing good. Character refers to a series of knowledge (cognitives), attitudes, and motivations, and behaviors, and skills (Mawardi, 2016).

Michael Novak's character is a compatible mix of all goodness identified by religious traditions, literary stories, wise men, and a collection of intelligent people (Tomas Lickona, 2012). Chaplin states that character is nature that is fixed and can be a characteristic for being able to distinguish one individual from another individual (Hapsari, 2016). Masnur, are the values of human behavior related to God Almighty, self, fellow human beings, the environment, and nationality that are manifested in thoughts of attitudes, feelings, words, and actions based on religious norms, law, manners, culture, and customs (Muslich, 2011). Character in Islam is called as akhlak. Al-Ghazali, akhlak is a condition that persists in the soul, all behavior comes from it without the need for thought and reflection. There are four moral principles, namely al hikmah (wisdom), asyyaya'ah (courage), al iffah (self-preservation) and al 'adl (justice) (Kurniawan, 2017).

Based on the opinion above, character can be called as akhlak, which is a state of nature, tendency of someone who stays in the heart in the form of knowledge, attitudes, behavior, habits that distinguish someone from others, in relation to God, self, others and the universe based on religious values, laws, and cultural customs that apply.

\section{E. Character Education in Early Childhood}

Character education is the deliberate effort to help people understand, care about, and act upon core ethical values. When we think about the kind of character we want for our children, it is clear that we want them to be able to judge what is right, care deeply about what is right, and then do what they believe to be right, even in the face of pressure from without and temptation from within (SM, Ismail, Agung, 2014). Character education is an effort to encourage early childhood to grow and develop, think and hold fast to moral principles and the courage to do the right thing, despite facing challenges (Wigunadika, 2018), touches the affective domain more than cognitive and psychomotor (Hadiyanto, 2016)

Ministry of National Education, said that character education is an effort to instill character values to students which includes knowledge, awareness or will, and actions to implement the values of goodness and virtue, to God, self, others, environment and nationality to become people with morality (Ministry of National Education, 2012)

According to Dafid Elkind and Freddy, the goal is to develop the potential of the heart/ conscience/ affective of students as human beings and citizens, develop commendable habits and behaviors and be in line with universal values and cultural traditions and develop the school environment as a safe, honest learning environment, creative and friendship (Zubaedi, 2011), not just teaching what is right and wrong, but instilling habits (habituation) about good so that children understand, are able to feel and want to do good (Marzuki, 2011), shaping character and noble character students as a whole, integrated and balanced, independent, behavingas the values of character and noble character that is manifested in everyday life (Hartoyo, 2011).

Character education will succeed optimally if the institution and all levels of the school focus on developing the vision and mission and the concept of a character school. To be more effective, the school climate must support character education programs (Berkowitz, 2018). Bloom, climate is a condition, influence, and external stimuli that include physical, social and intellectual influences that affect children and teachers. (Hadiyanto, 2018).

\section{F. The Importance of Character Education Since Early Childhood}

Albert Bandura and Walter Mische stated that a person's behavior, environment and cognition are the keys to success in development. When the child observes the behavior of others then he will involve cognitive function, and when repeating the behavior there is an extraordinary reinforcement (Rahayu, 2018). According to Megawangi that quality character needs to be shaped and nurtured from an early age. While Lickona stated, "a child is the only known subtance from which a responsible adult can be mode"(Megawangi, 2004).

Erikson and Brewer said that the success of children overcoming conflicts at an early age determines the success of children in social life in adulthood. (Christianti, 2015). Character education given to children from an early age will be firmly planted in the hearts and minds of children (Suyanto, 2012).

\section{G. Character Values in Early Childhood}

Character values are attitudes and behaviors that are based on norms and values that apply in society, which include spiritual aspects, personal / personality aspects, social aspects, and environmental aspects. Meanwhile, according to the technical instructions from the PAUD director general, character values planted in early childhood include four aspects, namely: spiritual aspects, personality aspects, social aspects, environmental aspects. (Ministry of National Education, 2012).

The values that are very important to be introduced and internalized into early childhood behavior include: love for God, honesty, discipline, tolerance and peace, selfconfidence, independence, help, cooperation, and mutual cooperation, respect and courtesy, responsibility, hard 
work, leadership and justice, creative, humble, care for the environment, love the nation and the motherland.

\section{H. The Principle of Character Education}

According to Lickona there are 11 principles for instilling effective character education values, contained in The Character Education Partnership, namely 1) Promotes core ethical values and supportive performance values as the foundation of good character, 2) defines "character" comprehensively to include thinking, feling, and behavior. 3) uses a comprehensive intentional, and proactive approach to character development, 4) creates a caring school community, 5) provides students with opportunities for moral action, 6) includes a meaningful and challenging academic curriculum that respects all leaners, develops their character, and help them to succeed, 7) strives to foster students' self motivation, 8) engages the school staff as a learning and moral community that shares responsibility for character education and attempts to adhere to the same core values that guide the education of students, 9) continued, 10) engages families and community members as partners in the character-building effort, 11) assesses the character of the school, the school staff's functioning as character educators, and the extent to which students manifest good character (Lickona, Tom, Eric Schaps, 2007).

Meanwhile, according to the technical guidelines for early childhood character education, there are seven principles that must be implemented in character education in PAUD, namely: through example and role model, carried out continuously, thoroughly, integrated in all aspects of development, creating an atmosphere of love, affection, actively motivating children, involving educators and education personnel, parents, and the community, the assessment. The assessment is intended not only for students, but also for the institution and all teaching staff and staff.

Based on the principles above, it can be concluded that in carrying out early childhood character education should be carried out as early as possible since the child enters school the first day, be programmed in the vision and mission of the school, integrated in all plans and activities, involving all parties related to the child, namely the teacher and all school residents, parents and families, and the community, through example and continual habituation as well as assessing both successes and constraints.

\section{Culture Based Early Childhood Character Education}

Bioecological theory, according to Brofenbrenner, is one of macrocytem which shows that the culture, customs and values of society in general could shape the lives of children. Culture is the group's way of life, including basic values, beliefs, religion, language, ways of dress, food, and various other practices (Morrison, 2012), the whole system of thinking, values, morals, norms, and beliefs of people who produced by society, which is the result of human interaction with others and the environment (S.Sriyono, 2010), anticipating a national crisis, how Huntington's opinion that the source of conflict in the future is no longer ideological or economic problems, but issues around culture. (Suryana, 2016). In the local culture has developed and accumulated noble education policies (Arzul, 2014). Education as a process of cultural transformation means education as an activity of cultural inheritance from one generation to another. Education is to perpetuate the culture in a relay, also to prepare students for the future (Suryana, 2013).

The main factors that can influence a child's development are the environment, culture and ethnicity (Hapsari, 2016). According to Ki Hajar Dewantara, character education based on local wisdom approaches that exist in early childhood environments, can be provided through games/dolanan, singing, fairy tales, sports, plays, languages, arts, religion and the natural environment (Magta, 2013), according to the opinion Lee, can be packaged in the form of games according to local culture (Lee, 2013). Ki Hajar also emphasized that the system that is in harmony with the identity of the Indonesian people, is the "among systems" namely Ing Ngarso Sung Tulodo, Ing Madyo Mangun Karso, Tut Wuri Handayani, as well as mutual cooperation between parents, teachers and the community (Pudjiastuti, Endang, 2015 ).

Vigotsky stated, the specific sociocultural context of learning and the development and cultural practices used in teaching and learning affect the development of higher mental functions within individuals or in certain groups (Roopnarine, 2011). The purpose of the cultural approach through local wisdom, is to explore the values of life, teach character, respect, courtesy and hold fast to culture as the nation's identity (Suprayogi, 2018).

\section{J. The Concept of Local Culture in Minangkabau Randai}

Kasim Achmad said that randai was derived from the word chain, meaning that the formation of players when randai performances were always in a circular position was like chaining (Achmad, n.d). Chairul Harun andai or handai, namely speaking by using the likeness, class, rhyme, and the saying of the petitih. Umar Kayam from Arabic is rayan-li-da-I which is very close to da-i preachers from the Naqshabandiyah tarekat movement. Yusuf Rahman, the double movements were named according to the Arabic calligraphic configuration of Alif, sitting Dal, Ba steps, and so on (Zulkifli, 2013).

According to Esten and Darwis, randai is the name of a dance form in Minangkabau whose movements are like pencak silat, played by several people in a circular formation (Arzul, 2014), taking small steps slowly, while conveying stories through alternating singing ( Hidayat, 2013), is a local wisdom, precisely in Labuah Basilang Dalam, Luhak Lima Puluh Koto area (Zulkifli, 1993), in which there is dialogue, like metaphors, rhymes, with movements accompanied by dendang (Zulkifli, 2013), a picture of identity a very strong society with the philosophy, ethics, and life lessons of Minangkabau people centered on nature (Bahardur, 2018).

Based on some of the opinions above it can be concluded that randai is an original Minangkabau cultural game played by several people with movements in a circular formation, containing stories, like metaphors, 
rhymes, and the saying of petitih by taking parables from the lives of the surrounding communities through songs and claps.

\section{K. Elements in Randai}

According to Suryadi (Arzul, 2014) there are two main elements in randai, namely: the element of storytelling $(k a b a)$ which is conveyed or presented through gurindam, elements of behavior and motion or dance that is delivered through waves with a variety of silat styles.

The revival of art is itself roped with the awakening of the mind (Hamka, 2015). Art elements in randai, namely: 1) Stories / Manuscripts, in story theater / texts called plays. Stories or kaba in randai contain communicative events, in the form of sentences (rhymes or dialogues). 2) Dendang (Gurindam), which serves to convey part of the story that was not acted for example to convey the atmosphere, time, travel, place of the incident, as well as to accompany the galombang (wave) motion. 3) Galombang, namely movements originating from pencak silat and played in a circle. The sayings of "hep ... ta ..." as a cue in the wave game randai. Galombang together with gurindam serves to transition between one scene to the next, (Zulkifli, 2013).

While the supporting elements are: 1) Music, which consists of internal and external music. Internal music is music that is born from the dancers while doing movements such as the sound of applause, clap galembong, pounding feet, clapping elbows, finger flickers, screams "hep ... yah ... tih ... hi. ..." and singing. External music is talempong,kendang or flute music. 2) Costumes, to symbolize the characters with their respective roles, for example as an antagonist, protagonist or as a player.

\section{Randai Based Early Childhood Character Education}

Randai as local wisdom contains values that are very appropriate to shape the character of early childhood. Local wisdom is knowledge developed by the ancestors in anticipating the environment around them, making it a part of culture and introducing and continuing it from generation to generation (Rahayu, 2018). According to Barokah, the values of local wisdom are the basic capital that is useful for learning the character of early childhood and delivering children to become wise humans in life (Eliza, 2017).

Bandura in the theory of learning by modeling, that character education in early childhood is to model good characters and explain them to children through reading stories, inviting children to play roles, telling stories about legends or "make beleave a story" which has a strong moral message in it (Suyanto, 2012). Through stories in randai, children also learn to use regional languages. The language used in randai uses the Minangkabau regional language. Roopnerine said, regional languages as cultural wealth must be taught and preserved. Every culture aims to maintain its personality and language. Early childhood education will become stronger, stronger and more robust and become richer with diversity in society (Roopnarine, 2011). Randai contains elements of the story that were extracted from the life of the Minang community. There are so many stories, legends, and stories from Minangkabau that contain local wisdom values that can shape the character of children in PAUD (Eliza, 2017). Stories will be of interest to young children if they are modified more simply, easily understood by children and the ability of the teacher to convey (Christianti, 2015). Stories or kaba in randai can foster religious character, respect, courtesy, and manners. According to Azwar, religious education if instilled from an early age, then when teenagers and adults will be able to select, choose and think twice about doing something that is forbidden by God (Arzul, 2014).

According to Conard et. al, through playing drama or role playing will be able to develop children's language skills and improve children's vocabulary ( $K$. Mages, 2015). In randai there is a script that contains the play, namely interaction in playing roles. According to Vygotsky that social interactions that occur in games can support and enhance children's cognitive development (Morrison, 2012). Randai also forms cooperation or cohesiveness among the players. The character of leaning to live together as one of the pillars of the educational vision of UNESCO (United Nations Educational, Scientific and Cultural Organization), which is an effort to shape personality to understand diversity, so as to give birth to a positive attitude and respond to differences or diversity (SM, Ismail, Agung, 2014).

Randai game contains drum music, claps, and simple musical instruments. Music in early childhood includes; singing, clapping and playing a simple musical instrument. According to Semiawan, through studying music a child can express experiences, help aspects of the child's development, namely physical-motor, language, social, emotional values, cognitive, refine and develop character values, and to develop children's right brain abilities. (Budiartati \& Jamaris, 2018). Thus, through randai can develop the abilities and values of character.

Movement in randai contains dance elements. Through the art of dance can help a conducive learning process and children's joy. Adding confidence, children's motivation to be honest, responsible, religious, love the country, and environmental care (Rakimahwati, 2014). Furthermore, according to Gilbert, by dancing children become accustomed to following instructions and respecting others. Meanwhile according to Bergstein and Pickup, through creative movements, acting in pairs or small groups, sharing in decision making and taking on different roles the child will have life skills (Pavlidou, Sofianidou, Lokosi, 2018).

\section{Learning through Play in Early Childhood Education.}

According to Froebel, playing is a child-centered activity, to get real experiences, be physically active, to relax, release energy, find new ideas or solutions and develop imagination. According to Smith and Pallgrini, a fun early childhood activity is not results-oriented, flexible, active and positive. (Musfiroh, 2014), Siregar, it can be used by children to explore their world, develop 
competencies and develop children's creativity without coercion (Suryana, 2018). Randai is a culture and is also called a native children's game because in doing so by playing without being oriented towards producing something like working, it can develop noble character values for young children.

\section{CONCLUSION}

Early childhood is the most valuable period in human life. Early childhood education is education to develop cognitive, affective and psychomotor abilities, namely intellectual, social, spiritual and moral as the basis for character formation. Randai is a game in the form of art which is full of local wisdom values in the form of religion, philosophy and ethics. Through the game of randai in early childhood, they will be able to form a strong character, as the base to prepare the golden generation to ward off the crisis of character while preserving the noble culture of the Minangkabau.

\section{REFERENCES}

[1] Achmad, K. (n.d.). Ungkapan Beberapa Bentuk Kesenian (Teater, wayang dan Tari). Jakarta: Direktorat Kesenian, Proyek Pengembangan Kesenian.

[2] Ahsanah, A. (2018). Implementasi Nilai Karakter Melalui Metode Bernyanyi untuk Anak Usia Dini di TK Satya Darma Sudjana Kecamatan Bandar Mataram Kabupaten Lampung Tengah. Skripsi.

[3] Alawiyah, F. (2012). Kebijakan pengembangan Pembangunan Karakter melaui Pendidikan di Indonesia. Jurnal Aspirasi, 3(1), 87-102.

[4] Amini, M. (2014). Hakikat Anak Usia Dini. Repocitory.ut.ac.id, 1-43. Retrieved from http://repository.ut.ac.id/4707/1/PAUD4306M1.pdf

[5] Arzul. (2014). Nilai-Nilai Pendidikan Karakter dalam Randai Bujang Sampai di Nagari Gunung Rajo kecamatan Batipuah Kabupaten Tanah Datar. Desertasi.

[6] Bahardur, I. (2018). Kearifan Lokal Budaya Minangkabau dalam Seni Pertunjukan Tradisional Randai. Jentera: Jurnal Kajian Sastra, 7(2), 145160

[7] Berkowitz, M. W. (2018). What works in values education. International Journal of Education Research, (December 2011), 153-158. https://doi.org/10.1016/j.ijer.2011.07.003

[8] Budiartati, E., \& Jamaris, M. (2018). Music Instructional to Develop Character Values for Early Childhood at Fishery Community Tambak Lorok Semarang City. Journal of Nonformal Education UNNES, 4(1), 47-56.

[9] Christianti, M. (2015). Pengenalan Karakter untuk Anak Usia Dini Melalui Cerita Rakyat Budaya Lokal. ePrints@UNY, 1-15. Retrieved from https://eprints.uny.ac.id/24092/
[10]Eliza, D. (2017). Pengembangan Model Pembelajaran Karakter Berbasis Cerita Tradisional Minangkabau untuk Anak Dini. PEDAGOGI: Jurnal Anak Usia Dini Dan Pendidikan Anak Usia Dini, 3(3b), 153-163.

[11] Hadiyanto. (2013). Manajemen Peserta Didik Bernuansa Pendidikan Karakter. Jakarta: AlWasat. Retrieved from http://repository.unp.ac.id/12922/

[12] Hadiyanto. (2016). Membantu Guru Meningkatkan Pendidikan Karakter Menuju Bangsa yang Beradab melalui Perbaikan Iklim Kelas. Prosiding KONASPI III, 1929-1935. Retrieved from http://www.seminars.unj.ac.id/konapsi

[13] Hadiyanto. (2018). Kindergarten Climate in Padang. Atlantis Press, 169(November). https://doi.org/10.2991/icece-17.2018.32

[14] Hamka. (2015). Kenang-kenangan Hidup Buku Dua (I). Jakarta: PT Balai Pustaka (Persero).

[15] Hapsari, I. I. (2016). Psikologi Perkembanagn Anak (cet I). Jakarta: Indeks.

[16] Hartoyo, h. A. (2011). Potensi Pembinaan Karakter Berbasis Budaya Masyarakat, 1, 19-30.

[17] Hidayah, Y. (2015). Membangun Karakter Anak Sejak Usia Dini Melalui Tri Pusat Pendidikan. Prosiding, 2015-2222.

[18] Hidayat, R. (2013). Upaya Penggalakan Randai dan Nagari Ampu. E-Jurnal Sendratasik, 2(1), 7585.

[19] K. Mages, W. (2015). Educational Drama in Early Childhood Promoting Language Development and Supporting Literacy Transitions. Open Online Journal Padagogishe Hochschule Niederosterreich, (September), 1-5.

[20] Kaimuddin. (2014). Implementasi Pendidikan Karakter Dalam Kurikulum 2013. Dinamika Ilmu, 14(1), 47-64. https://doi.org/10.1061/(ASCE)07339410(1991) 117

[21] Kemdiknas. (2012). Pedoman Pendidikan Karakter pada Pendidikan Anak Usia Dini. Jakarta.

[22] Khadijah. (2016). Pengembangan kognitif anak usia dini. Medan: Perdana Publishing.

[23] Kurniawan, S. (2017). Pendidikan karakter dalam Islam Pemikiran Al-Ghazali tentang Pendidikan Karakter Anak Berbasis Akhlaq al-Karimah. Tadrib, 3(2), 197-215.

[24] Larasati, T. A. (2010). Pemanfaatan Nilai-Nilai Luhur Warisan Budaya Bangsa dalam Pendidikan Anak Usia Dini. Widyariset, 13(1), 135-143.

[25] Lee, G.-L. (2013). Re-emphasizing Character Education in Early Childhood Programs: Korean Children's Experiences. Childhood Education, 89(5), 315-322. https://doi.org/https://doi.org/10.1080/00094056.2 
013.830907

[26] Lickona, Tom, Eric Schaps, \& C. lewis. (2007). CEP' s Eleven Principles of Effective Character Education. Washington, DC: Character Education Partnership.

[27] Lickona, T. (2004). Character Matters How to Help Our Childre Develop Good Judment, integrity, and other Essential Virtues. New York: Simon \& Schuster.

[28] Lickona, T. (2012). Mendidik untuk Membentuk Karakter. Bagaimana Sekolah dapat Memberikan Pendidikan Sikap Hormat dan Bertanggung Jawab (Penerjemah Juma ABdu Wamaungo. Jakarta: Bumi Aksara.

[29] Lukitasari, F. (2017). Implementasi Kurikulum Pendidikan Berbasis Budaya dalamPengembangan Karakter Anak di TK Pedagogia. Skripsi.

[30] Magta, M. (2013). Konsep Pendidikan Ki Hajar dewantara pada Anak Usia Dini. Jurnal Pendidikan Usia Dini, 7(2), 221-232.

[31] Marzuki. (2011). Pembinaan karakter siswa berbasis pendidikan agama. Jurnal Kependidikan, 41(1), 45-53.

[32] Marzuki. (2015). Kebijakan Nasional Pendidikan Budaya dan Karakter Bangsa. FIS UNY, 1-50. Retrieved from http://staff.uny.ac.id/sites/default/files/lain-lain/drmarzuki-mag/7-ppt-dr-marzuki-kebijakannasional-pendidikan-budaya-dan-karakter-bangsacompatibility-mode.pdf

[33] Mawardi, D. (2016). Pendidikan untuk Pengembangan Karakter ( Telaah terhadap Gagasan Thomas Lickona dalam Educating for Character ). Al-Ulum, 14(January), 269-288.

[34] Mayar, F. (2013). Perkembangan sosial anak usia dini sebagai bibit untuk masa depan bangsa. AlTa'lim, I(6), 459-465.

[35] Megawangi, R. (2004). Pendidikan Karakter. Jakarta: Indonesia Heritage Fondation.

[36] Morrison, G. S. (2012). Dasar-Dasar Pendidikan Anak Usia Dini. (Febrianti, Ed.) (Kelima). Jakarta: Indeks.

[37] Mulyatiningsih, E. (2011). Analisis Model-Model Pendidikan Karakter untuk Usia Anak-Anak, Remaja dan Dewasa. Jurnal Uny.ac.id, 1-18.

[38] Musfiroh, T. (2014). Teori dan Konsep Bermain. Modul PAUD UT4201, 1-44. Retrieved from http://repository.ut.ac.id/4699/1/PAUD4201M1.pdf

[39] Muslich, M. (2011). Pendidikan Karakter: Menjawb Krisis Multidimensional. Jakarta: Bumi Aksara.

[40] Pavlidou, Sofianidou, Lokosi, \& K. (2018). Creative dance as a tool for developing preschoolers, communicative skills and movement expression. Journal, European Psychomotricity, (1988), 3-15.
[41] Prasetyo, N. (2011). Membangun Karakter Anak Usia Dini Seri Bacaan Orang Tua. Jakarta: Dirjend PAUD Kemdiknas.

[42] Pudjiastuti, Endang, N. C. (2015). Developing Early Childhood Aducation Model That Excellent and Characterized Based on Local Wisdom. International Conference on Chilcren Issues, 1-8.

[43] Rahayu, S. (2018). Penanaman Nilai-Nilai Kearifan Lokal dalam Pembentukan Karakter Anak Usia Dini di Kecamatan Marioiwawo Kabupaten Soppeng. Eprint.unm.ac.id, 1-11. Retrieved from https://scholar.google.com/scholar?hl=id\&as_sdt= $0 \% 2 \mathrm{C} 5 \& \mathrm{q}=$ penanaman + nilai-

nilai+kearifan+lokal+dalam+pembentukan++kara kter+di+soppeng\&btnG $=$

[44] Rakimahwati. (2014). Character Development through Dance Learning in an Early Childhood Setting. IJECES, 3(2), 102-107. https://doi.org/10.15294/ijeces.v3i2.9490

[45] Roopnarine, J. L. (2011). Pendidikan Anak Usia Dini dalam Berbagai Pendekatan (kelima). Jakaerat: Kencana.

[46] S.Sriyono. (2010). Pengembangan Pendidikan Budaya dan Karakter Bangsa Melalui Integrasi Mata Pelajaran, Pengembangan dan Budaya Sekolah. Universitas Terbuka, 1-17. Retrieved from http://repository.ut.ac.id/2557/1/fkip201031.pdf

[47] SM, Ismail, Agung, M. (2014). "Learning to Live Together": Penanaman Karakter pada Anak Usia Dini di Lembaga PAUD Islam. Al-Ulum, 14(1), 229-246.

[48] Suprayogi, A. (2018). Fenomena lagu dolanan "Gundul-Gundul Pacul" dalam Pendidikan Karakter Anak dan Ranah Sosial. Imaji, 16(2), 109-117.

[49] Suryana, D. (2013). Pendidikan Anak Usia Dini (Teori dan Praktek Pembelajaran). UNP Press Padang. Retrieved from https://anzdoc.com/suryana-dadan-pendidikananak-usia-dini-teori-dan-praktik-pe.html

[50] Suryana, D. (2016). Character Building for Young Children Based on the Values of Cultural Universality of Indonesia. Indonesian Journal of Early Childhood Education Studies 4, (February), 21-28.

[51] Suryana, D. (2018). Stimulasi \& Aspek Perkembanagn Anak. Jakarta: Kencana.

[52] Suyanto, S. (2012). Pendidikan Karakter untuk Anak Usia Dini. Jurnal Pendidikan Anak Usia Dini, 1-10(1), 1-10.

[53] Warsiti. (2015). Pembelajaran Berbasis Budaya Lokal dalam Membentuk Karakter Toleransi pada Anak Kelompok B di TK Negeri Pembina Kabupaten Purbalingga. Skripsi, 1-90.

[54] Wibowo, T. (2019). Rahasia Sukses Pendidikan 
Karakter 7 Hari Membentuk Karakter Anak. Surabaya: Pendidikan Karakter.com.

[55] Wigunadika, I. W. S. (2018). Pendidikan Karakter Berbasis Kearif Lokal Masyarakat Bali. Purwadita: Jurnal Agama Dan Budaya, 2(2), 91100.

[56]Zubaedi. (2011). Desain Pendidikan Karakter: Konsepsi dan Aplikasinya dalam Lembags Pendidikan. Jakarta: Kencana.

[57]Zulkifli. (1993). Randai sebagai Teater Rakyat minangkabau di Sumatera Barat dalam Dimensi Sosial Budaya. Tesis. Jogjakarta: Universitas Gadjah Mada.

[58]Zulkifli. (2013). Randai Sebagai Teater Rakyat Minangkabau: Alternatif Pembinaan dan Pengembangan. Garak Jo Garik JurnalPenciptaan Seni, 9(1), 30-45. Retrieved from http://www.journal.isi-

padangpanjang.ac.id/index.php/Garak/article/view /204 